УДК $550.4: 553+553.41$

\title{
МИНЕРАЛОГО-ГЕОХИМИЧЕСКАЯ И ИЗОТОПНО-УГЛЕРОДНАЯ ТИПИЗАЦИЯ МЕТАЛЛОНОСНЫХ ОБРАЗОВАНИЙ ЦЗЯМУСЫ-ХАНКАЙСКОЙ ГРАФИТОНОСНОЙ ПРОВИНЦИИ (Приморский край)
}

\author{
В. П. Молчанов ${ }^{1}$, Д. В. Андросов ${ }^{2}$ \\ ${ }^{I}$ ФБУУН Дальневосточный геологический институт ДВО РАН, г. Владивосток \\ ${ }^{2} O O О$ «ИТЕР», г. Дальнереченск \\ E-mail:vpmol@mail.ru, androsov64@mail.ru
}

\begin{abstract}
В пределах единой зоны региональной графитизации, вытянутой в субмеридиональном направлении на многие десятки километров сопредельных территорий Приморского края и провинции Хэйлунцзян (КНР), с участием авторов предлагаемой работы обнаружены многочисленные проявления благороднометалльной минерализации. На северном фланге зоны расположены объекты Дальнереченской группы (наиболее крупное - Филинское), в центре - месторождения Лесозаводской группы (Тургеневское, Тамгинское), на юге графитоворудный гигант Люмао. Сравнительным анализом установлены черты сходства их геологии, минералогии и геохимии. Результаты изотопно-углеродного изучения российских и китайских графитов свидетельствуют об участии в рудогенезе производных глубинных восстановленных флюидов и изотопно-легкого биогенного вещества вмещающих пород. Выявленные черты сходства минералого-геохимических картин формирования объектов в пределах изученной зоны, обусловленные общими источниками рудного вещества, позволяют отнести их к одной и той же графитоносной Цзямусы-Ханкайской провинции.
\end{abstract}

Ключевые слова: высокоуглеродистые породы, юг Дальнего Востока РФ, Северо-Восток КНР, графит, золото, платина, редкоземельные элементы, минералогия, геохимия, изотопия, глубинные источники рудного вещества.

DOI: 10.34078/1814-0998-2019-2-11-21

\section{ВВЕДЕНИЕ}

Высокоуглеродистые породы занимают обширные территории в пределах Дальнего Востока РФ и Северо-Востока Китайской Народной Республики (КНР). Только в Приморском крае они образуют широкую зону, вытянутую в субмеридиональном направлении на многие десятки километров вдоль границы Ханкайского и Цзямусы террейнов от г. Дальнереченск на севере через г. Лесозаводск до г. Цзиси (провинция Хэйлунцзян, КНР) (рис. 1).

В пределах зоны установлен ранний этап регионального метаморфизма низкоградиентного широкозонального типа в условиях амфиболитовой и эпидот-амфиболитовой фаций, возраст которого составил 730 млн лет. Поздний этап метаморфизма от гранулитовой до зеленосланцевой фаций связан с коллизионными событиями на рубеже кембрия и ордовика. Один из важнейших результатов геологических исследований последних десятилетий в пределах

(C) Молчанов В. П., Андросов Д. В., 2019 этой зоны - открытие (Ханчук и др., 2004) проявлений благороднометалльно-редкоземельной минерализации. В ее северной, российской, части (Дальнереченская площадь) выявлено пять месторождений (наиболее крупное из них Филинское), в центре (Лесозаводская площадь) расположено свыше 30 объектов (в том числе известные месторождения графита Тамгинское и Тургеневское), а в южном, китайском, сегменте (Машаньская площадь) размещено около 40 месторождений, в том числе и графитоворудный гигант Люмао, на долю которого приходится более половины мировой добычи кристаллического графита. Учитывая широкое площадное проявление металлоносных графитизированных пород при их значительной мощности по вертикали (до 3000 м), можно полагать, что они, помимо графита, аккумулируют значительные ресурсы благородных металлов (БМ) и редкоземельных элементов (РЗЭ). Было предложено (Ханчук и др., 2017) объединить упомянутые графитоносные площади в общую Цзямусы-Ханкайскую провинцию. 


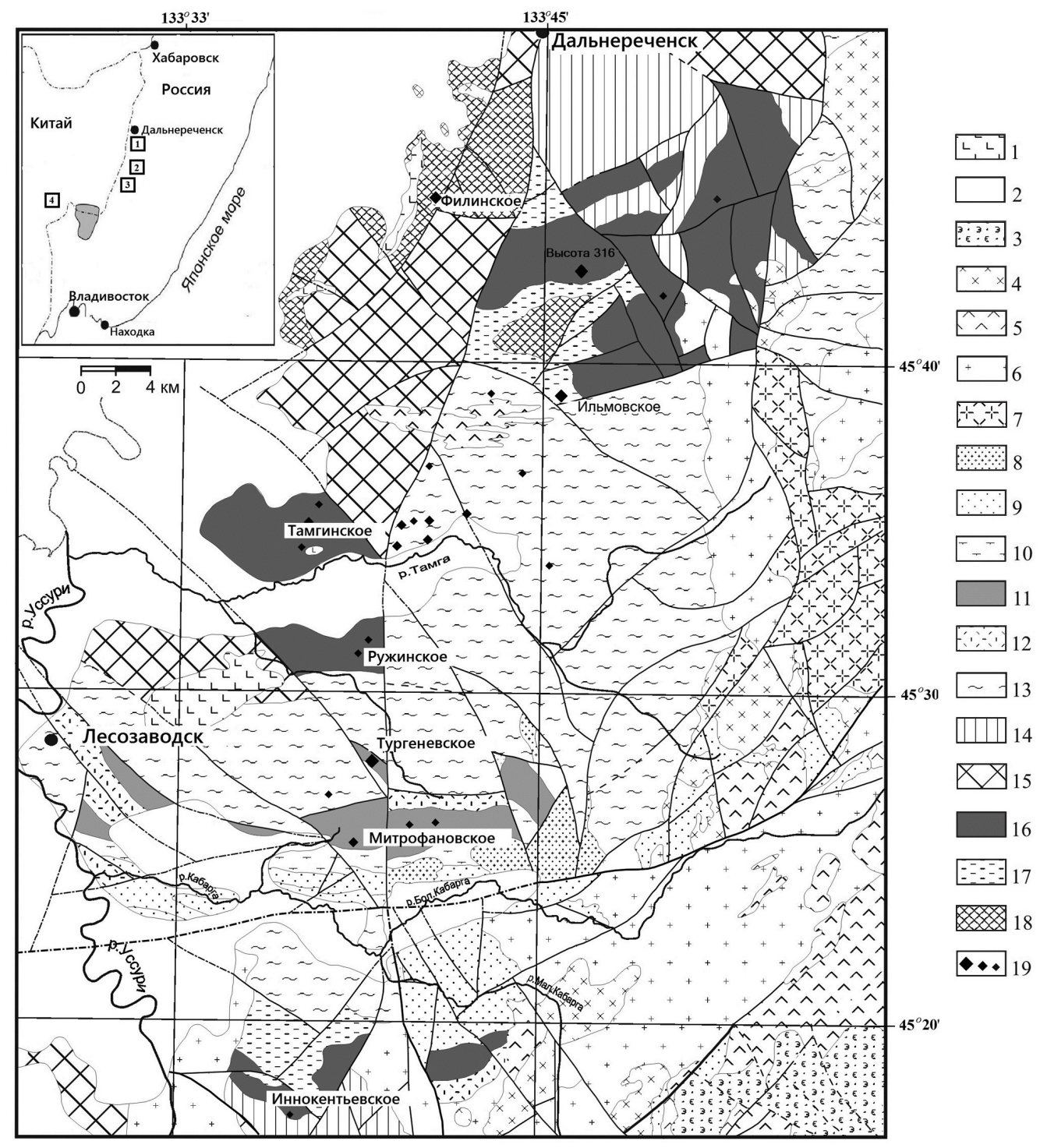

Puc. 1. Геологическая карта проявлений благороднометалльно-редкоземельно-графитоносных руд Дальнереченской и Лесозаводской площадей (составлена по материалам АО «Дальневосточное ПГО» с дополнениями и изменениями авторов). На врезке показано местоположение Филинского (1), Тамгинского (2), Тургеневского (3) и Люмао (4) месторождений Цзямусы-Ханкайской графитоносной провинции: 1 - неогеновые базальты; 2 - кайнозойские осадочные отложения; 3 - нижнемеловые дациты и их туфы; 4 - раннемеловые граниты; 5 - нижнепермские риолиты и их туфы; 6 - раннепермские граниты; 7 - нижнедевонские песчаники, сланцы, известняки; 8 - раннеордовикские граниты; 9 - нижнекембрийские графит-серицит-хлоритовые сланцы, кварциты, известняки, базальты, марганцевые руды; 10-13 - позднепротерозойские образования: 10-12 - лесозаводская серия: 10 - биотит-серицитовые сланцы (кабаргинская свита), 11 - высокоуглеродистые графитовые сланцы, кварциты, мрамора (спасская свита), 12 - графитовые кристаллические сланцы, кварциты, мрамора (спасская свита), 13 - графитовые гнейсы, кристаллические сланцы, амфиболиты, мрамора (уссурийская серия, тургеневская свита); 14-17- иманская серия, матвеевская свита: 14 - гнейсы, 15 - графитовые гнейсы, кварциты, мрамора, эвлиазиты, 16 - высокоуглеродистые графитовые гнейсы, кварциты, мрамора, эвлиазиты, 17 - графитовые кристаллические сланцы, мрамора; 18 - иманская серия, ружинская свита - графитовые мрамора, кальцифиры, гнейсы; 19 - месторождения и рудопроявления графита

Fig. 1. Geological map of the precious-rare-earth-graphite-bearing ores of the Dalnerechenskaya and Lesozavodskaya areas (based on the materials of the Far East PGO JSC, added and changed by the authors). The inset shows the location of the Filinskoye (1), Tamginskoye (2), Turgenevskoye (3), and Liumao (4) deposits in the Jiamusi-Khanka graphitic province: 1 - Neogene basalts; 2 - Cenozoic sediments; 3 - Lower Cretaceous dacites and their tuffs; 4 - Early Cretaceous granites; 5 - Lower Permian rhyolites and their tuffs; 6 - Early Permian granites; 7 - Lower Devonian sandstones, shales, limestones; 8 - Early Ordovician granites; 9 - Lower Cambrian graphite-sericite-chlorite schists, quartzites, limestones, basalts, manganese ores; 10-13 - Late Proterozoic formations: 10-12 - Lesozavodskaya series: 10 - biotite-sericite shales (Kabarginskaya Suite), 11 - high-carbon graphite shales, quartzites, marbles (Spasskaya Suite), 12 - graphite crydstalline schists, quartzites, marbles (Spasskaya Suite), 13 - graphite gneisses, crystalline schists, amphibolites, marbles (Ussuriyskaya series, Turgenevskaya Suite); 14-17 - Imanskaya series, Matveevskaya Suite: 14 - gneisses, 15 - graphite gneisses, quartzites, marbles, eulysites, 16 - high-carbon graphite gneisses, quartzites, marbles, eulysites, 17 - graphite crystalline schists, marbles; 18 Imanskaya series, Ruzhynskaya Suite - graphite marbles, calciphyres, gneisses; 19 - graphite deposits and occurrences 
Однако на фоне детально изученных проявлений благороднометалльно-редкоземельной минерализации центральной части провинции южный и северный фланги в российской геологической литературе освещены слабо. Многие вопросы происхождения и концентрирования БМ и РЗЭ, их связей с углеродистым веществом требуют серьезного уточнения, что и вызвало необходимость в проведении дополнительных минералогогеохимических и изотопно-углеродных изысканий. Главными инструментами послужили результаты минералого-геохимических и изотопноуглеродных исследований металлоносных образований. Отбор проб осуществляли из карьеров и керна буровых скважин, обнажений вмещающих пород и рудных образований большинства известных к настоящему времени объектов Дальнереченской, Лесозаводской и Машаньской графитоносных площадей.

\section{МЕТОДЫ ИССЛЕДОВАНИЙ}

Минералогические исследования выполняли с применением электронно-зондового микроанализатора Jeol Superprobe JXA 8100 с системой INCA Energy 350 Oxford Instruments и электронного сканирующего микроскопа EVO500XVP с системой INCA Energy 350 Oxford Instruments.

Анализ микроэлементного состава проб был проведен согласно методике, адаптированной к графитоносным породам (Ханчук и др., 2014), на масс-спектрометре с индуктивно связанной плазмой (ИСП-МС) Agilent 7500c (Agilent Technologies, Япония), оборудованном распылителем Бабингтона, охлаждаемой распылительной камерой Скотта и заземленной горелкой Фассела. Использовались никелевые конусы самплера и скиммера. Петрогенные элементы определяли на атомно-эмиссионном с индуктивно связанной плазмой спектрометре iCAP 6500 Duo (ИСПАЭС) (Thermo Scientific, США).

Изотопный анализ углерода в графитизированных породах проведен на изотопном массспектрометре Finnigan MAT 253 с использованием двойной системы напуска. Подготовка образцов к масс-спектрометрическому изотопному анализу углерода выполнена по методике окисления углерода на окислительной колонке $\mathrm{CuO}$ (Веливецкая и др., 2006). Анализируемый образец смешивали с порошком оксида меди, предварительно прокаленного при $900^{\circ} \mathrm{C}$ на атмосфере в течение 30 мин. Готовую смесь помещали в кварцевый реактор, загружали реакционную колонку и откачивали $\leq 10^{-3}$ мм рт. ст. для удаления сорбированных газов и паров воды. Окисления углерода проводили в вакууме при температуре $850^{\circ} \mathrm{C}$. Эффективность конверсии обеспечивает предварительно нагретая до $850^{\circ} \mathrm{C}$ колонка $\mathrm{CuO}$. Про- дукты реакции вымораживали в ловушку $-196^{\circ} \mathrm{C}$ и осуществляли криогенную очистку $\mathrm{CO}_{2}$. Воспроизводимость метода составляет $\pm 0.1 \%$.

\section{РЕЗУЛЬТАТЫ ИССЛЕДОВАНИЙ И ИХ ОБСУЖДЕНИЕ}

Многие наукоемкие технологии, являющиеся показателями уровня развития промышленного производства передовых стран, немыслимы без использования графита. Уникальные свойства этого минерала вместе с последними открытиями в области ядерной энергетики, электроники и нанотехнологий полностью поменяли наше представление о возможностях его использования. В странах Европейского Содружества и Китае графит внесен в список критических минералов. Основные месторождения высококачественного кристаллического графита находятся в Китае, Индии, Бразилии, Чехии, Канаде и Мексике. При этом основным производителем и экспортером графитового сырья является Китай. Немногочисленные российские предприятия, специализирующиеся на добыче графита, лишь в малой степени обеспечивают потребности нашей страны в графитовой продукции. Основная часть кристаллического графита ввозится из-за рубежа. Одним из направлений обеспечения национальной безопасности России является создание новых центров добычи и переработки графитовых руд высокого качества. Выполненные исследования позволят наметить основные направления промышленного освоения российских месторождений графита юга Дальнего Востока, их комплексного использования и глубокой переработки высокоуглеродистого минерального сырья.

\section{1. Минералого-геохимическая характеристика}

Дальнереченская металлоносная площадь

Наиболее крупное месторождение площади, Филинское, открытое с участием авторов (Khanchuk et al., 2018), приурочено к породам нижней (ружинской) свиты рудовмещающего разреза отложений иманской серии $\left(\mathrm{PR}_{1}\right)$. Специфика его рудных образований состоит в тесной связи с процессами регионального метаморфизма, проявившегося в условиях от гранулитовой до амфиболитовой фации. Комплекс рудовмещающих пород представлен переслаиванием мраморов, кальцифиров, биотит-кварцполевошпатовых сланцев и согласных инъекций биотитовых и лейкократовых гранито-гнейсов. Породы сильно дислоцированы, смяты в антиклинальную складку субмеридионального простирания. Восточное крыло складки прорвано штоком лейкократовых гранитов. Отмечается присутствие секущих слоистую толщу маломощных жил, сложенных кварцем и полевым шпатом. По контактам с гранитами и гранито-гнейсами 
мрамора скарнированы. В мраморах и сланцах графит в ассоциации с сульфидами и флюоритом развит в виде тонкочешуйчатой равномерно рассеянной вкрапленности, в скарнах и гранитогнейсах образует крупные мономинеральные гнезда, жилы и прожилки.

Рудная минерализация, ассоциирующая с графитом, характеризуется сложным полиминеральным составом. Самородное золото чаще всего представлено частицами неправильных очертаний. Диапазон гранулометрической шкалы этих обособлений невелик (10-20 мкм). По химическому составу их можно отнести к высокопробным разновидностям. Лишь в отдельных золотинах фиксируется примесь $\mathrm{Cu}$ до 1-2\%. Самородное серебро обнаружено в виде проволоковидных выделений размером до 10-15 мкм. В некоторых из них присутствует $\mathrm{Cu}$ $(0.9 \%)$. В ассоциации с минералами БМ и графитом отмечаются сульфиды (пирит, пирротин, пентландит, халькопирит, сфалерит, Со-содержащий арсенопирит, галенит, висмутин, тетрадимит), а также барит, рутил, монацит, ксенотим, уранинит. Наряду с ними довольно часто встречаются зерна Ybсодержащего (до 1\%) флюорита, образующего с кварцем графические срастания.

В изученных графитизированных породах установлен широкий спектр элементов. Отличительными чертами рудовмещающих пород являются повышенные концентрации $\mathrm{Al}_{2} \mathrm{O}_{3}$ и щелочей при преобладании $\mathrm{Na}_{2} \mathrm{O}$ над $\mathrm{K}_{2} \mathrm{O}$, а также $\mathrm{Y}$, $\mathrm{Cr}, \mathrm{Zn}, \mathrm{Ni}, \mathrm{Rb}, \mathrm{Zr}, \mathrm{Ba}, \mathrm{Pb}$, Th.

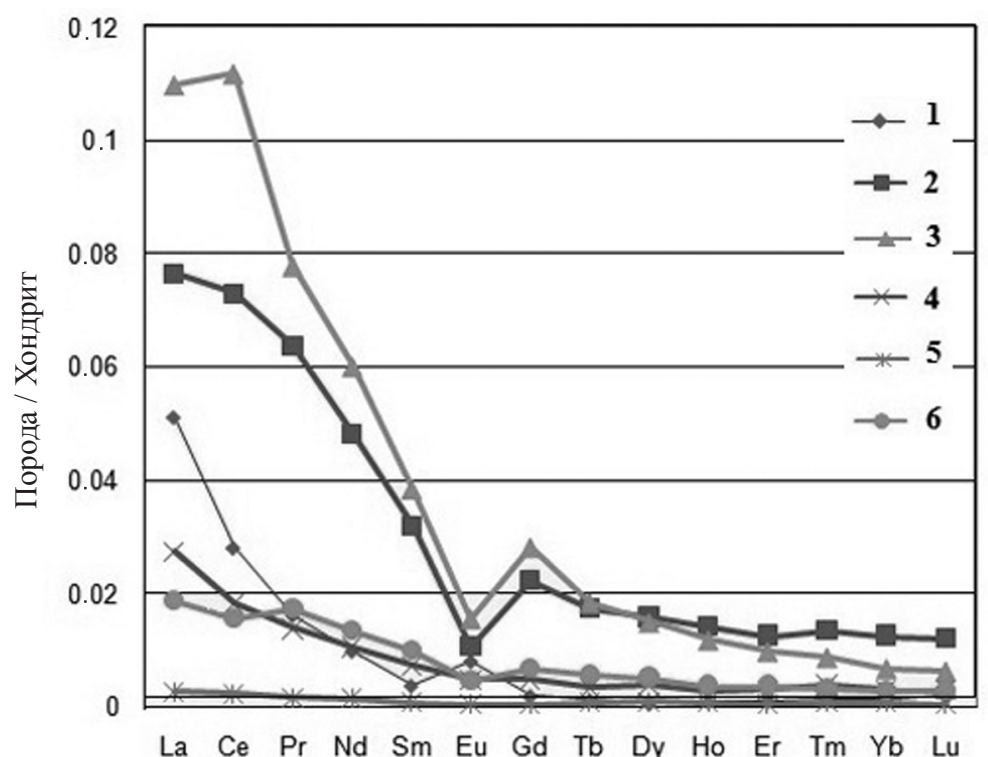

Рис. 2. Характер распределения РЗЭ в графитоносных породах месторождения Филинское: 1 - граниты; 2 - скарны; 3 - гранитогнейсы; 4 - графитовые руды; 5 - кварцевые жилы; 6 - биотиткварц-полевошпатовые сланцы

Fig. 2. Nature of REE distribution in graphite-bearing rocks of the Filinskoye deposit: 1 - granites; 2 - skarns; 3 - granite-gneisses; 4 graphite ores; 5 - quartz veins; 6 - biotite-quartz-feldspar shales
По характеру распределения РЗЭ графитоносные породы разделяются на две группы: одна с низким суммарным содержанием РЗЭ и положительной европиевой аномалией и другая с более высоким содержанием Р3Э и отрицательной европиевой аномалией (рис. 2). В первую группу попадают граниты, во вторую - все остальные разновидности пород изученной площади. Различия в амплитуде европиевой аномалии могут отражать разную глубину магматического очага. Тренды распределения Р3Э в гранитах описываются кривыми, отражающими резкое обогащение легкими и средними лантаноидами относительно тяжелых (отношение $\mathrm{La} / \mathrm{Yb}$ достигает 55, $\mathrm{La} / \mathrm{Sm}$ - 16.5). Суммарное содержание Р3Э составляет 59 г/т.

Углеродистым породам второй группы свойственно значительное преобладание легких РЗЭ над тяжелыми. Максимальные концентрации Р3Э зафиксированы у углеродистых сланцев ( $\sum$ Р3Э до 740 г/т, La/Yb - 110-120). Им близки хондрит-нормализованные тренды распределения РЗЭ в скарнах, графитовых жилах и гранитогнейсах. Они также обогащены легкими РЗЭ относительно тяжелых (La/Yb 11-24), но располагаются в области более низких концентраций РЗЭ. Кварцевые жилы представлены компактной группой трендов, отражающих максимальное снижение всех РЗЭ ( 2 РЗЭ до 5-11 г/т). Им свойственна незначительная европиевая аномалия, а также уменьшение отношения $\mathrm{La} / \mathrm{Sm}$ и $\mathrm{Gd} / \mathrm{Yb}$. Это выражается в слабом проявлении дифференциации как среди легких, так и тяжелых лантаноидов.

Все отмеченные разновидности пород графитизированы, концентрация элементарного углерода в отдельных случаях достигает 20 мас.\%. Выполненные анализы указывают на наличие тенденции снижения степени графитизации пород в направлении от скарнов к кварцевым жилам. Более того, сопоставление полученных данных показало, что в образцах с повышенными содержаниями графита и золота (0.1-0.2 г/т) постоянно присутствуют значительные количества лантаноидов. Тесная ассоциация редкоземельных и благородных металлов с графитом свидетельствует в пользу их генетического родства, являясь признаком происхождения из единого рудогенерирующего источника. Этот факт имеет важное прикладное значение, поскольку позволяет не только контролировать качество исходного благороднометалльно-редкоземельно-графитового материала, но 
и корректировать направление будущих технологических исследований.

\section{Лесозаводская металлоносная площадь}

Критическая ситуация с графитовым сырьем в современной России вызвала интерес к выявленным в прошлом высокоуглеродистым породам юга Дальнего Востока, в частности, Тургеневскому и Тамгинскому месторождениям. Разведочными работами 1940-х гг. (Солоненко, 1951) они были отнесены к числу крупнейших в СССР источников кристаллического графита. Им посвящены многочисленные публикации сотрудников ДВГИ ДВО РАН (Ханчук и др., 2004, 2010 и т. д.), установивших присутствие значительных ресурсов благородных металлов. В этих работах дана детальная характеристика по минералогии и петрографии пород и руд, приводятся сведения об изотопно-геохимических особенностях рудных образований, рассматриваются проблемы их генезиса. Основные исследования авторов посвящены Тургеневскому месторождению. Согласно цитированным источникам, оно расположено в Ружинском метаморфическом комплексе, в ядре которого вскрыт эрозией комплекс пород верхней тургеневской свиты уссурийской серии, измененных в условиях амфиболитовой фации (участок «Западный»). Комплекс представлен переслаиванием гранат-биотит-полевошпатовых, биотит-кварц-полевошпатовых кристаллосланцев и плагиогнейсов с мраморами и согласными инъекциями биотитовых и лейкократовых очковых гранито-гнейсов. Мрамора на контакте с гранито-гнейсами скарнированы. Отмечается присутствие маломощных (до 1 м) согласных со сланцеватостью даек лампрофиров габбродиоритового состава щелочного (калиевого) уклона. На крыльях Ружинского купола обнажены позднепротерозойские черные апотерригенные аспидные и филлитовидные графит-серициткварцевые сланцы митрофановской свиты лесозаводской серии, с высоким (до 12 мас.\%) содержанием углерода (участок «Восточный»). Степень их метаморфизма отвечает зеленосланцевой фации. Представленные на месторождении литологические разности пород подвержены процессам наложенной графитизации в виде дисперсных фаз, мономинеральных жил и линзовидных включений. В кристаллосланцах графит ориентирован согласно слоистости, в то время как в гранито-гнейсах и лампрофирах преобладают секущие прожилки и линзовидные скопления.

Содержание углерода варьирует от долей процента до 39 мас.\%. Наивысшая степень графитизации наблюдается в малых интрузивных телах гранитов, прорывающих описываемый комплекс. Источником углерода в магматических протолитах могли быть как глубинные восстановленные флюиды, так и первично рассеянный магматический углерод. Установлены следующие соотношения графита с минералами в графитизированных гранито-гнейсах: графит кристаллизуется одновременно с другими фазами, образуя взаимные прорастания с кварцем и биотитом. Наблюдаются как пересечения скоплений биотита графитовыми прожилками, так и секущие прожилки биотита в графите, что свидетельствует о синметаморфическом образовании графита.

Рудная минерализация, ассоциирующая с графитом, характеризуется довольно сложным полиминеральным составом и многообразием форм распределения благородных и редкоземельных металлов в виде самородных элементов и интерметаллических соединений. Наряду с ними присутствуют бронза $(\mathrm{Cu}, \mathrm{Sn})$, разновидности латуни (двухкомпонентой - $\mathrm{Cu}-\mathrm{Zn}$ и мышьяковистой с примесью свинца и серы).

В графитовых рудах самородное золото нередко образует микронные и субмикронные выделения в виде сфероидальных обособлений (до 2 мкм), состав которых обнаруживает значительные колебания от 1000 до 980\%. Спорадически в золоте отмечаются примеси $\mathrm{Ag}, \mathrm{Cu}, \mathrm{Hg}$ (до 1-2\%). Помимо золота, в графите присутствуют мелкие включения интерметаллидов следующего состава, мас.\%: $\mathrm{Pd}-58.10, \mathrm{Au}-24.5, \mathrm{Ag}-10.53$, $\mathrm{Sn}-6.86$. Наряду с ними встречаются выделения неправильной формы интерметаллических соединений $\mathrm{Cu}$ и $\mathrm{Fe}$ сечением до 2.5 мкм. Помимо простых соединений $\mathrm{Ag}$ и $\mathrm{Au}$, обнаружены более сложные по составу интерметаллиды, мас.\%: $\mathrm{Au}$ - 9.09-6.27, Ag - 3.59-2.27, Sn - 21.54-19.79, $\mathrm{Pd}-1.88, \mathrm{Si}-12.02-12.59, \mathrm{Al}-0.69-0.64, \mathrm{Na}-$ 1.47-1.95, O - 46.39-43.61, C - 0.1-6.87.

Самородное золото в скарнах отличают комковидно-губчатая форма, более крупные (до 1 мм) размеры и повышенное (до 10 мас.\%) содержание Ag. На поверхности его зерен образуется углеродистая нанопленка, в составе которой, помимо С (56-60 мас.\%), присутствуют О (19$33 \%$ ) и примесь $\mathrm{Si}, \mathrm{Al}, \mathrm{Ca}, \mathrm{Fe}$ и $\mathrm{Cl}$ (до 1 мас.\%).

Наиболее низкопробная разновидность микрокристаллического золота состава, мас.\%: $\mathrm{Au}-60-65, \mathrm{Ag}-33-34, \mathrm{Cu}-1-2$ встречается в прожилково-вкрапленных зонах. В нем обнаружена примесь, мас.\%: U - 3.42, W - 1.26 и постоянно присутствует фтор со значительными колебаниями содержания от единиц до 34.66 мас.\%. Уменьшение температуры кристаллизации из рудоносного флюида сопровождается понижением пробности золота (за счет роста содержания серебра). При этом на частицах самородного серебра обнаружены микроагрегаты галогенидов в виде сростков иодаргирита (AgI), иодобромита $(\mathrm{Ag}(\mathrm{I}, \mathrm{Br}))$ и кераргирита $(\mathrm{AgCl})$. Эти обособления галогенидов приурочены, как правило, к 
углеродистым участкам. Сложность состава фаз в одном и том же микроагрегате, их наноразмерность говорят о высокой скорости формирования зерен. Отсутствие фтора, появление примеси иода и брома означают гораздо более низкую температуру кристаллизации из флюида серебряной минерализации по сравнению с золотой. Самородная платина представлена дискретными зернами неправильной формы, равномерно рассеянными в графитовой и силикатной матрице пород (участок «Западный»). В графит-серициткварцевых сланцах обнаружены единичные тонкопризматические кристаллы изоферроплатины, мас.\%: $\mathrm{Pt}-90.36, \mathrm{Fe}-9.64$. В графитовых метасоматитах Тамгинского месторождения встречены близкие по размерам и форме призматические кристаллы платины, содержащие примесь других элементов, мас.\%: $\mathrm{Pt}-79.31, \mathrm{Cu}-2.09$, $\mathrm{Si}-1.03, \mathrm{O}-8.93, \mathrm{C}-8.65$. В силикатной матрице графитистых сланцев (Тамга) присутствуют таблитчатые выделения интерметаллидов, мас.\%: $\mathrm{Pt}-38.2, \mathrm{Sn}-38.2, \mathrm{Pd}-3.29, \mathrm{Fe}-0.89$, $\mathrm{Si}-1.52, \mathrm{O}-27.50$. При травлении свежих сколов образцов черных сланцев участка «Восточный» обнаружены микроагрегаты иридия с примесью редких земель. Они имеют неправильную форму, состоят из дисперсных зерен переменного состава и всегда с примесью кобальта и меди.

В графитизированных породах установлен широкий спектр элементов от петрогенных

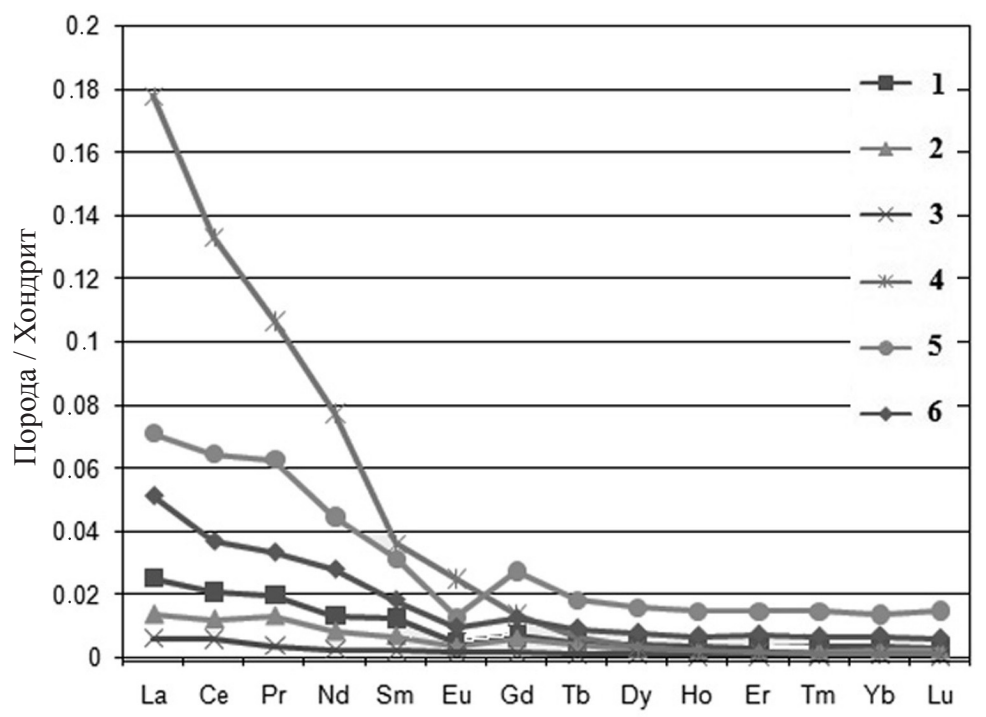

Рис. 3. Хондрит-нормализованные тренды распределения РЗЭ в углеродистых породах месторождений Лесозаводской группы: 1 - скарны; 2 - кварцевые жилы; 3 - кварц-карбонатные жилы; 4 - лампрофиры; 5 - биотит-кварц-полевошпатовые жилы; 6 графитовые руды

Fig. 3. Chondrite-normalized trends of REE distribution in carbonaceous rocks of the Lesozavodskaya group deposits: 1 - skarns; 2 quartz veins; 3 - quartz-carbonate veins; 4 - lamprophyres; 5 - biotitequartz-feldspar veins; 6 - graphite ores вплоть до $\mathrm{Au}, \mathrm{Pt}, \mathrm{Hg}, \mathrm{Cu}, \mathrm{Sn} \mathrm{La}, \mathrm{Ce}$ и редких земель. Наиболее высокие содержания РЗЭ характерны для лампрофиров, в которых их суммарные содержания достигают 1 мас.\%. Кроме того, результаты комплекса анализов свидетельствуют о том, что в лампрофирах концентрируется максимум БМ, г/т: $\mathrm{Pt}-62, \mathrm{Au}-49, \mathrm{Pd}-1.1$ и $\mathrm{Rh}-5, \mathrm{Ag}-8.2$. Содержание золота в графитизированных гранито-гнейсах, графит-серициткварцевых сланцах и скарнах варьирует в широких пределах, достигая 17.41, 13.01 и 8.50 г/т соответственно.

Анализ подвижности РЗЭ в различных процессах показал, что они мобильны при гидротермальных и метасоматических процессах, менее мобильны при низко- и умеренно температурном метаморфизме и условно инертны при высокотемпературном метаморфизме. Имеющиеся данные (рис. 3, 4) указывают, что по характеру распределения Р3Э графитоносные породы, как и в случае с Филинским месторождением, разделяются на две группы: первая представлена гранитами, во вторую входят все остальные разновидности пород изученной площади, включая низкотемпературные гидротермальные образования. Близки у них и конфигурации графиков распределения микроэлементов. Граниты характеризуются той же положительной европиевой аномалией и резким преобладанием легких лантаноидов над тяжелыми (отношение $\mathrm{La} / \mathrm{Yb}$ достигает 118). Суммарное содержание РЗЭ составляет 93 г/т.

Породам второй группы, так же как филинским, свойственны отрицательная европиевая аномалия и значительное преобладание легких лантаноидов над тяжелыми. Наиболее тяжелые концентрации РЗЭ зафиксированы у скарнов, лампрофиров и амфиболитов ( $\sum$ РЗЭ до 255 г/т, La/Yb - 1218). В области более низких концентраций Р3Э расположены кристаллосланцы, графит-серицит-кварцевые сланцы. Отношение La/Yb при этом варьирует от 6 до 11. Минимальные концентрации Р3Э (до 18-21 г/т) имеют кварцевые и кварц-карбонатные жилы, располагаясь в нижней части графика субгоризонтальной компактной группой. Выполненные анализы содержаний элементного углерода показывают, что дифференциация РЗЭ сопровождается снижением степени графитизации в направлении от скарнов к жилам. При этом, как и в рудных образованиях Филинского месторождения, отмечается наличие корреляции между содержаниями зо- 
лота, графита и Р3Э. Тесные связи редкоземельных и благородных металлов с графитом в месторождениях Дальнереченской и Лесозаводской площадей еще раз свидетельствуют в пользу их генетического родства, являясь признаком происхождения из единого рудогенерирующего источника.

\section{Машаньская металлонос- ная площадь}

Графитоворудный гигант Люмао в структурном плане приурочен к террейну Цзямусы. Специфика его рудных образований определяется тесными связями с высокоуглеродистыми породами серии Машань, претерпевшими метаморфизм от гранулитовой до амфиболитовой фации. В геологическом строении объекта принимают участие гранатсиллиманитовые, силлиманитгранат-кордиеритовые, графитовые и кварцевые сланцы, гранито-гнейсы, переслаивающиеся с мраморами (рис. 5). Для рудовмещающих пород характерны щелочной (калиевый) уклон, высокие концентрации $\mathrm{Al}_{2} \mathrm{O}_{3}, \mathrm{TiO}_{2}$ и низкие $-\mathrm{Na}_{2} \mathrm{O}, \mathrm{CaO}$. Имеет место отрицательная корреляция между содержаниями $\mathrm{SiO}_{2}$ и $\mathrm{Al}_{2} \mathrm{O}_{3}$ и $\mathrm{TiO}_{2}$. Последние характеризуются положительными корреляционными связями. Графитоносным образованиям свойственны повышенные содержания элементарного углерода (до 40 мас.\%), а также $\mathrm{U}, \mathrm{V}, \mathrm{Ag}$. В то же время, как показывают наши исследования, в высокоуглеродистых породах по данным атомно-абсорбционной спектрометрии содержания золота достигают $0.12-0.15$ г/т, а платины - 0.01-0.02 г/т. Близкие значения были получены с применением методов нейтронноактивационного анализа.

Диаграммы распределения редкоземельных элементов (рис. 6) показывают, что графитоносные породы серии Машань обогащены легкими лантаноидами, для них характерны отрицательная европиевая аномалия и низкие концентрации тяжелых редкоземельных элементов. Сопоставление их с графиками распределения редкозе-

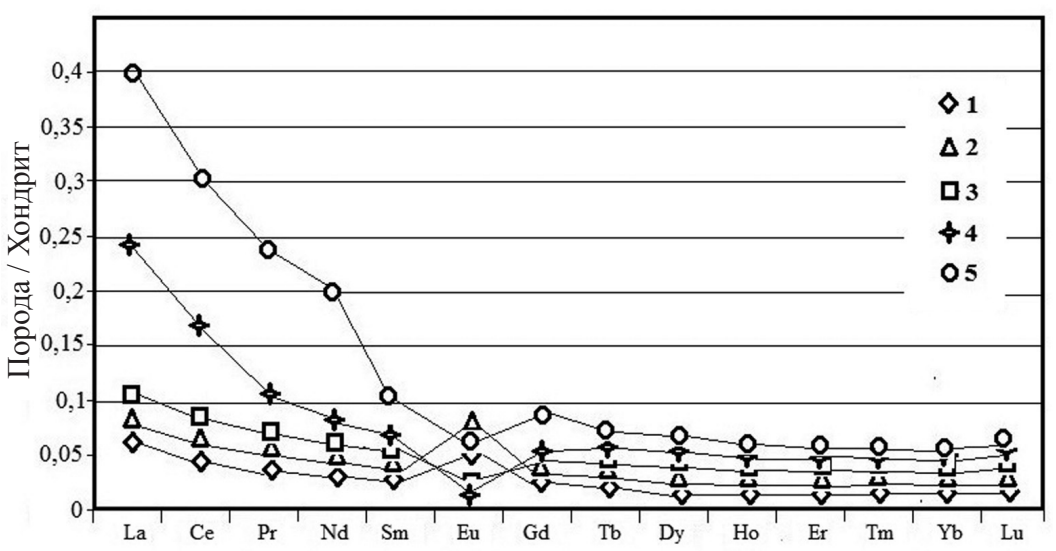

Puc. 4. Распределение РЗЭ в гранито-гнейсах (1-3) и гранитах $(4,5)$ месторождений Цзямусы-Ханкайской графитоносной провинции: 1, 5 - Дальнереченская группа; 2, 4 - Лесозаводская группа; 3 - Машаньская группа

Fig. 4. REE distribution in granite-gneisses $(1-3)$ and granites $(4,5)$ from deposits of the Jiamusi-Khanka graphitic province: 1,5 - Dalnerechenskaya group; 2, 4 - Lesozavodskaya group; 3 - Mashanskaya group

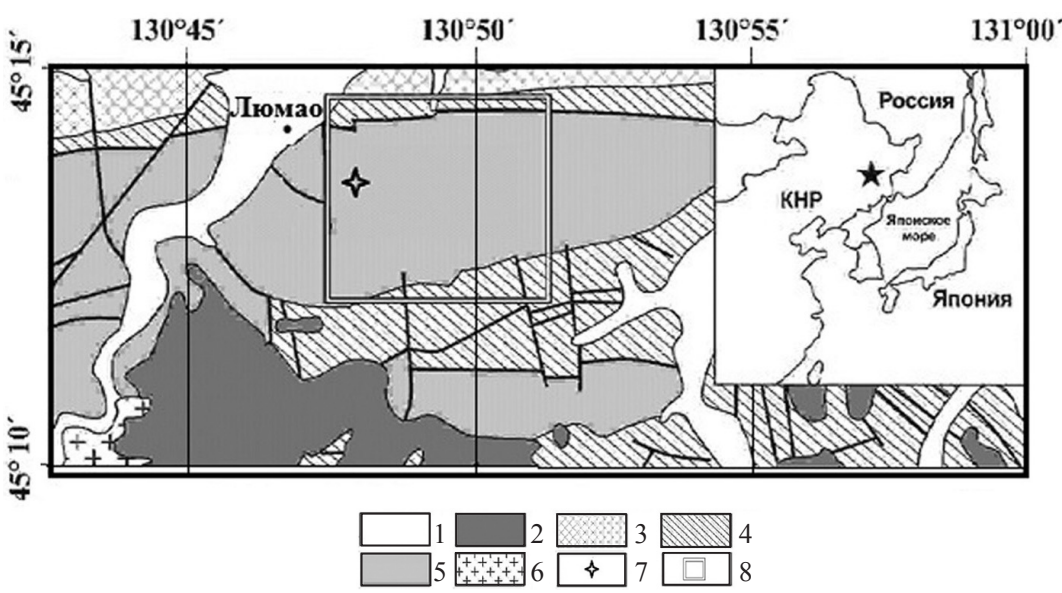

Puc. 5. Схема геологического строения района месторождения Люмао: 1 - четвертичные отложения; 2 - плиоценовые базальты; 3 - нижнемеловые песчаники, сланцевые песчаники; 4 - верхнеюрские песчаники, алевролиты, сланцы, галечники, угли; 5 - позднепротерозойские образования серии Машань: гранулиты, гнейсы, мрамора, графитовые сланцы; 6 - гранито-гнейсы; 7 - место отбора проб; 8 - площадь рудолокализации месторождения Люмао

Fig. 5. Scheme of the geological structure of the Liumao deposit area: 1 - Quaternary deposits; 2 - Pliocene basalts; 3 - Lower Cretaceous sandstones, shale sandstones; 4 - Upper Jurassic sandstones, siltstones, shales, pebbles, coals; 5 - Late Proterozoic formations of the Mashan series: granulites, gneisses, marbles, graphite shales; 6 - granite-gneisses; 7 - sampling spot; 8 - ore localization area of the Liumao deposit

мельных элементов в породах месторождений Лесозаводской и Дальнереченской площадей показывает синформность кривых всех типов пород, что однозначно указывает на их единую природу происхождения.

Рудная минерализация, ассоциирующая с графитом, характеризуется сложным полиминераль- 


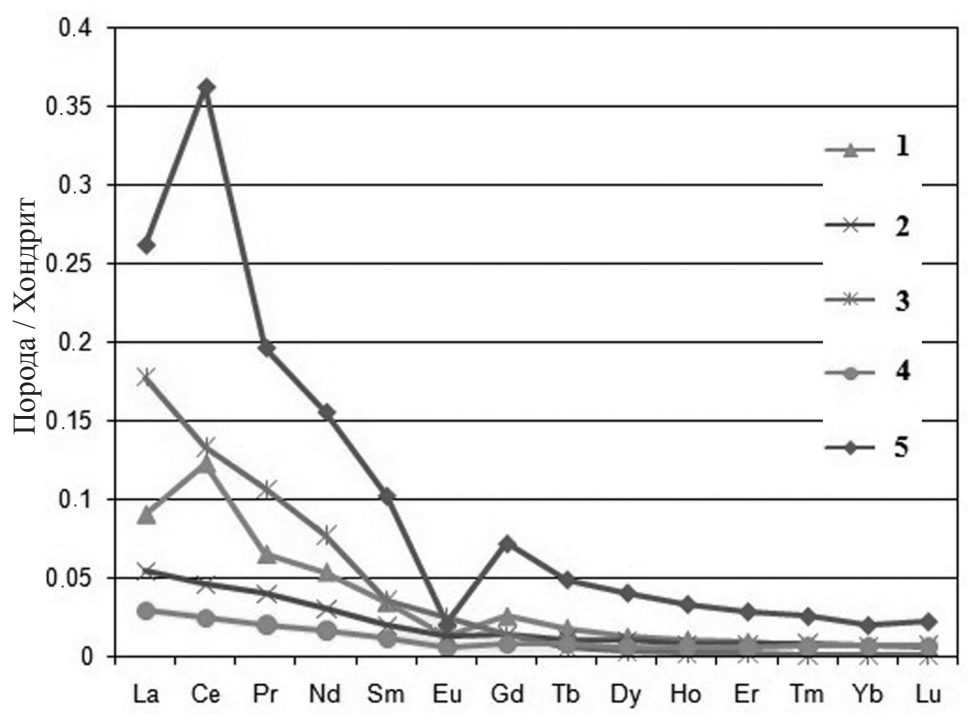

Рис. 6. Хондрит-нормализованные тренды распределения РЗЭ в углеродистых породах месторождения Люмао: 1 - гранитогнейс; 2 - графитовые сланцы; 3-5 - графитовые руды

Fig. 6. Chondrite-normalized trends of REE distribution in carbonaceous rocks of the Liumao deposit: 1 - granite-gneiss; 2 graphite shales; $3-5$ - graphite ores

ным составом и разнообразием форм распределения благородных металлов в виде самородных элементов, твердых растворов. Самородное золото чаще всего представлено частицами неправильных форм. Диапазон гранулометрической шкалы этих обособлений невелик (1-10 мкм). По химическому составу они подразделяются на четыре группы: беспримесную, серебристую, медистую и серебросодержащую медистую. Первая из них объединяет золотины с очень высокой частотой (до 999 ед.), вторая - частицы с содержанием Ag от 5.13 до 51.92 мас.\%. В третью группу входят медьсодержащие (Cu обычно от 0.92-1.37 мас.\%, максимальное значение до 12.75 мас.\%) без примеси серебра. Четвертая группа включает обособления трехкомпонентных твердых растворов Au-Ag-Cu. Концентрация серебра в них не превышает 8.3 мас.\%, а уровень содержания меди варьирует от 14.3 до 29.6 мас.\%.

В зафиксированных зернах твердого раствора на основе платины содержание железа и меди колеблется в диапазоне 8.7-10.9 и 1.4-1.5 мас.\% соответственно. Размеры этих комковидных либо удлиненно-неправильных частиц обычно не превышают 2-3 мкм. Самородное серебро обнаружено в виде округлых выделений размером от 3 до 15 мкм. В некоторых из них присутствует медь (0.4 0.5 мас.\%). В ассоциации с минералами БМ часто фиксируются изометричные зерна (до 6 мкм) самородного никеля. В число других попутных минералов входят сульфиды (пирит, галенит), а также барит, рутил, монацит, ксенотим, хромферид, уранинит. Наряду с ними довольно редко встре- чаются тонкие минеральные фазы, содержащие вольфрам, ртуть, олово, медь, цинк, стронций и др.

Таким образом, полученная информация по самородным золоту, платине, никелю и другим рудным минералам графитоносных пород месторождений Люмао хорошо согласуется с приведенными данными по минералогии и геохимии месторождений Дальнереченской и Лесозаводской групп, что свидетельствует в пользу общности минералого-геохимической картины формирования рудоносных объектов в пределах зоны региональной графитизации.

\section{2. Изотопно-углеродный состав графитов}

Ключом к расшифровке природы рудного вещества может послужить «визитная карточка» ЦзямусыХанкайской провинции - графит, а точнее, изотопный состав его углерода. Образование графита в природе, как отмечалось ранее (Галимов, 1968), возможно при метаморфизме органического вещества, воздействии магматических интрузий на карбонатные породы, восстановлении из флюида мантийного происхождения, насыщенного $\mathrm{CH}_{4}, \mathrm{CO}, \mathrm{CO}_{2}$. Поскольку эти источники характеризуются различными значениями изотопных соотношений ${ }^{13} \mathrm{C} /{ }^{12} \mathrm{C}$, то эти параметры можно считать индикаторами генезиса графита. Так, изотопные характеристики углерода органического вещества варьируют в диапазоне $\delta^{13} \mathrm{C}$ от -17 до -40\%о при средних значениях $-26 \ldots$ -28\% (Hoefs, 2015). Морские карбонаты $\left(\delta^{13} \mathrm{C}\right.$ от -2 до $+2 \%$ ) и мантийный углерод (от -5 до -7\%о) по изотопно-углеродному весу значительно тяжелее органического вещества (Luque et al., 2012). В нашем случае все эти источники графитов совмещены в пределах Цзямусы-Ханкайской провинции, что несколько усложняет интерпретацию полученной изотопной информации. Наиболее подходящими для выяснения источников рудного вещества являются графиты из гранитогнейсов или сланцев, поскольку в этом случае можно избежать влияния изотопного обмена с карбонатным углеродом.

Как показали наши исследования, графиты российских гранито-гнейсов по изотопному составу обладают достаточно высокой степенью гомогенности и изменяются в интервале от -3.2 до -8.8\%о, что указывает на мантийный источник углерода. При этом значения $\delta^{13} \mathrm{C}$ графита Филинского месторождения (нижняя свита рудовмещающего разреза) варьируют от -3.2 до 
-5.1\%о, тогда как для графитов Тургеневского месторождения (участок «Западный»), локализованного в породах верхней свиты, характерны более низкие значения $\delta^{13} \mathrm{C}$ (от -8.5 до $-8.8 \%$ ). Еще более изотопно-легким оказался графит китайских гранито-гнейсов $\left(\delta^{13} \mathrm{C}\right.$ достигает $-11.5 \%$ )

Аналогичную картину мы наблюдаем при сопоставлении изотопных составов графитов российских и китайских сланцев. Диапазон изменений $\delta^{13} \mathrm{C}$ из зон дробления сланцев Филинского месторождения составил от -11.1 до -11.5\%о. Графит из сланцев Тургеневского месторождения (участок «Восточный») содержит в себе более изотопно-легкий углерод с $\delta^{13} \mathrm{C}$ от -19.3 до $-26.6 \%$. Близкие значения $\delta^{13} \mathrm{C}$ характерны и для графита из сланцев Люмао (до -26.3\%о).

Полученные данные по изотопии углерода графита российских и китайских месторождений позволяют полагать, что в формировании сингенетичной им рудной минерализации провинции участвовали по меньшей мере два изотопно-контрастных источника: флюиды мантийного происхождения и осадочные породы с органическими соединениями. Широкие вариации изменений изотопного состава углерода $\left(\delta^{13} \mathrm{C}\right.$ от -3.2 до $\left.-26.6 \%\right)$ отражают различный вклад биогенного углерода. В любом случае главными поставщиками углерода при формировании благороднометалльно-редкоземельнографитоносных руд были глубинные флюидные потоки.

Резюмируя сказанное, отметим, что исследование закономерностей распределения БМ, Р3Э и углерода, а также форм их выделения в рудных образованиях Дальнереченской, Лесозаводской и Машаньской площадей позволило установить несколько этапов формирования полигенной благороднометалльно-редкоземельной минерализации. На первом этапе формируются графитовые руды, связанные с длительным функционированием мантийного очага и проявлением интрузивного магматизма. Благородные и редкоземельные металлы, углерод мантийного происхождения транспортировались сухими восстановленными флюидами к поверхности. Путями их движения стали легко проницаемые зоны скрытых глубинных разломов в осадочном чехле Цзямусы и Ханкайского террейнов. Отложение рудного вещества осуществлялось в восстановительной среде, свидетельством чего служит широкий набор самородных элементов и интерметаллидов. Высокотемпературные флюиды могут переносить металлы в виде металлоорганических соединений с хлором, фтором, кислородом, серой и другими летучими компонентами. Группы C = O, входящие в состав углеродистого вещества, вступают в реакции присоедине- ния, формируя летучие карбонилы металлов. В условиях метаморфизма эти соединения диссоциируют, разлагаясь по схеме $\mathrm{Mx}(\mathrm{CO}) \mathrm{y}=\mathrm{xM}+\mathrm{yCO}$, и металл переходит из возбужденного состояния в нейтральное. Это объясняет широкое развитие редкоземельных, в первую очередь, легких лантаноидов в углеродистых комплексах. Формирующееся таким образом видимое золото обычно обладает высокой пробностью, что было показано нами для руд раннего этапа, сопряженного с графитизацией.

На втором, скарновом, этапе происходила перекристаллизация рудного вещества с образованием новых микропарагенезисов БМ и Р3Э нередко при участии углеродистого вещества (УВ). При этом золото часто выступало в качестве подложки для формирования углеродистых и редкоземельных микро-наноструктур.

Третий, наиболее поздний гидротермальный этап связан с участием в становлении зон прожилково-вкрапленной минерализации гидротермальных растворов, продуцируемых поздними гранитоидами, что заметно сказалось на составе самородного золота, в котором появились заметные примеси Ag, W, F, U. Рудообразование сопровождалось перекристаллизацией и переносом УВ вмещающих пород, что оказывало определенное влияние на снижение концентрации РЗЭ.

\section{ЗАКЛЮЧЕНИЕ}

Сравнительный анализ месторождений Дальнереченской, Лесозаводской и Машаньской групп (см. таблицу) обнаруживает удивительную близость их геолого-геохимических и изотопных характеристик. Выделим наиболее яркие черты подобия рассматриваемых объектов:

1) палеопротерозойский возраст рудовмещающих пород;

2) приуроченность к единой зоне регионального метаморфизма;

3) общие источники рудного вещества;

4) направленность эволюции минералообразующего процесса от графитовых руд к скарнам и гидротермалитам. Наблюдаемые различия в минералого-геохимической специализации рудных образований отражают существование, как минимум, двух контрастных геохимических зон - нижнерудной (Филинское месторождение) и верхнерудной (Тургеневское и Люмао). При этом если золото занимает устойчивые позиции на каждом из двух уровней, то платина является геохимическим индикатором лишь месторождений верхней зоны.

Приведенные материалы по геологии, минералогии, геохимии и изотопии металлоносных образований высокоуглеродистых пород сопредельных территорий юга Дальнего Востока РФ и Северо-Востока КНР позволяют достаточно обоснованно отнести площади рудолокализа- 
Геолого-геохимические и минералогические особенности российских и китайских месторождений Цзямусы-Ханкайской графитоносной провинции

Geological-geochemical and mineralogical features of the Russian and Chinese deposits in the Jiamusi-Khankai graphitic province

\begin{tabular}{|c|c|c|c|}
\hline \multirow{2}{*}{$\begin{array}{c}\text { Геолого-геохимическая } \\
\text { и минералогическая } \\
\text { характеристика }\end{array}$} & \multicolumn{3}{|c|}{ Месторождение } \\
\hline & Филинское & Тургеневское & Люмао \\
\hline $\begin{array}{l}\text { Вмещающие породы (воз- } \\
\text { раст) }\end{array}$ & \multicolumn{3}{|c|}{ Гнейсы, кристаллические сланцы, мраморы (палеопротерозой) } \\
\hline Интрузивные образования & Гранитоиды & Гранитоиды, лампрофиры & Гранитоиды \\
\hline Геохимический спектр & $\begin{array}{c}\mathrm{Au}, \mathrm{Cr}, \mathrm{Rb}, \mathrm{Zr}, \mathrm{Ba}, \mathrm{Th}, \mathrm{Y} \\
\mathrm{Pb}, \mathrm{Zn}\end{array}$ & $\mathrm{Au}, \mathrm{Pt}, \mathrm{La}, \mathrm{Ce}, \mathrm{Hg}, \mathrm{Cu}, \mathrm{Sn}$ & $\mathrm{Au}, \mathrm{Pt}, \mathrm{Ag}, \mathrm{U}, \mathrm{V}$ \\
\hline Самородные металлы & $\mathrm{Au}, \mathrm{Ag}, \mathrm{Ni}, \mathrm{Co}$ & $\mathrm{Au}, \mathrm{Ag}, \mathrm{Pt}$ & $\mathrm{Au}, \mathrm{Ag}, \mathrm{Ni}$ \\
\hline $\begin{array}{l}\text { Металлические твердые } \\
\text { растворы и интерметалли- } \\
\text { ческие соединения }\end{array}$ & $\begin{array}{c}(\mathrm{Au}, \mathrm{Cu}),(\mathrm{Ag}, \mathrm{Cu}),(\mathrm{Ni} \\
\mathrm{Co}, \mathrm{Fe}),(\mathrm{Fe}, \mathrm{Cr})\end{array}$ & $\begin{array}{c}(\mathrm{Au}, \mathrm{Ag}),(\mathrm{Au}, \mathrm{Hg}) \\
(\mathrm{Au}, \mathrm{Cu}),(\mathrm{Au}, \mathrm{Ag}, \mathrm{Cu}, \mathrm{Hg}), \\
(\mathrm{Au}, \mathrm{Pd}, \mathrm{Ag}, \mathrm{St}),(\mathrm{Au}, \mathrm{Ag}, \\
\mathrm{U}, \mathrm{F}),(\mathrm{Pt}, \mathrm{Fe}, \mathrm{Cu}),(\mathrm{Cu}, \\
\mathrm{Sn}),(\mathrm{Cu}, \mathrm{Zn})\end{array}$ & $\begin{array}{c}(\mathrm{Au}, \mathrm{Ag}),(\mathrm{Au}, \mathrm{Cu}),(\mathrm{Au} \\
\mathrm{Ag}, \mathrm{Cu}),(\mathrm{Pt}, \mathrm{Fe}, \mathrm{Cu}),(\mathrm{Fe} \\
\mathrm{Cr}),(\mathrm{Ag}, \mathrm{Cu})\end{array}$ \\
\hline Сульфиды & $\begin{array}{c}\text { Пирит, пирротин, халько- } \\
\text { пирит, сфалерит, галенит, } \\
\text { арсенопирит, пентландит, } \\
\text { тетрадимит }\end{array}$ & $\begin{array}{c}\text { Киноварь, пирит, сфале- } \\
\text { рит, галенит, халькопирит }\end{array}$ & Пирит, сфалерит, галенит \\
\hline $\begin{array}{l}\text { Оксиды, фосфаты, фто- } \\
\text { риды }\end{array}$ & $\begin{array}{c}\text { Уранинит, монацит, ксе- } \\
\text { нотим, флюорит }\end{array}$ & Уранинит, мон & ацит, ксенотим \\
\hline $\begin{array}{l}\text { Изотопный анализ угле- } \\
\text { рода графита (кол-во ана- } \\
\text { лизов) }\end{array}$ & $\begin{array}{c}\text { Гнейсы от }-3.2 \text { до -5.1\%о } \\
\text { Сланцы от }-11.1 \text { до } \\
-11.5 \% \text { (21) }\end{array}$ & $\begin{array}{c}\text { Гнейсы от }-8.5 \text { до }-8.8 \% \text { o } \\
\text { Сланцы от }-19.3 \text { до } \\
-26.6 \% \text { (28) }\end{array}$ & $\begin{array}{c}\text { Гнейсы до -11.5\%о } \\
\text { Сланцы от }-19.3 \text { до } \\
-26.3 \% \text { (26) }\end{array}$ \\
\hline
\end{tabular}

ции месторождений Лесозаводской, Дальнереченской и Машаньской групп к одной и той же графитоносной Цзямусы-Ханкайской провинции. Принадлежность графитоносных объектов к этой провинции в дальнейшем может служить основой для решения важных генетических вопросов, моделирования процессов рудообразования в высокоуглеродистых породах, совершенствования приемов переработки графитового материала.

Так, промышленное освоение приморских месторождений графита сдерживается из-за отсутствия технологий извлечения полезных компонентов. В этих условиях представляется необходимым учесть многолетний опыт технологического передела руд китайского аналога месторождения Люмао, обеспечивающего до 70\% потребности КНР в кристаллическом графите.

Работа выполнена при поддержке гранта РФФИ № 17-05-00910.

\section{ЛИТЕРАТУРА}

Веливеикая Т. А., Игнатьев А. В., Рейзе М. В., Кияшко С. И. Экспрессный метод подготовки жидких и твердых проб органических веществ для изотопного анализа углерода // Масс-спектрометрия. 2006. Т. 3, № 3. C. 169-174.
Галимов Э. М. Геохимия стабильных изотопов углерода. М. : Недра, 1968. 226 с.

Солоненко В. П. Геология месторождений графита Восточной Сибири и Дальнего Востока. М. : Изд-во геол. лит-ры, 1951. 383 с.

Ханчук А. И., Сун Фенгуй, Молчанов В. П. и др. Благородные металлы в графитосодержащих породах месторождения Люмао (Китай) // Докл. РАН. 2017. T. 473, № 1. С. 80-82.

Ханчук А. И., Плюснина Л. П., Молчанов В. П. Первые данные о золото-платиноидном оруденении в углеродистых породах Ханкайского массива, Приморье // Там же. 2004. Т. 379, № 4. С. 524-529.

Ханчук А. И., Медков М. А., Молчанов В. П., Бло-

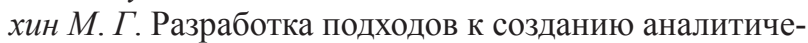
ских методов и технологии извлечения полезных компонентов из графитоносных пород // Химическая технология. 2014. № 6. С. 378-384.

Hoefs J. Stable Isotope Geochemistry. Berlin : Springer, 2015. $402 \mathrm{p}$.

Khanchuk A. I., Molchanov V., Androsov D. V. First data about the manifestations of the noble-metallicallyrare-earth mineralization in the graphytonic rocks of the northern market of the Khankai terrain // Doklady Earth Sciences. 2018. 482 (2). 1362-1364.

Luque, F., Crespo Feo, E., Barrenechea, J., Ortega, L. Carbon isotopes of graphite: Implications on fluid history // Geoscience Frontiers. 2012. 3. 197-207. 


\title{
MINERALOGICAL-GEOCHEMICAL AND ISOTOPIC-CARBON TYPIFICATION OF METALLIFEROUS FORMATIONS IN THE JIAMUSI-KHANKA GRAPHITIC PROVINCE (Primorsky Krai)
}

\author{
V. P. Molchanov ${ }^{\text {, D. D. Androsov }}{ }^{2}$ \\ ${ }^{1}$ Far East Geological Institute, FEB RAS, Vladivostok \\ ${ }^{2}$ ITERA Limited Co., Dalnerechensk
}

\begin{abstract}
Within a single zone of regional graphitization, extended in the submeridional direction for many tens of kilometers of adjacent territories of Primorsky Kray, Russia, and the Heilundzyan Province, China, with the participation of the authors of the paper, numerous manifestations of the preciousmetal mineralization were revealed. On the northern flank of the zone, the Dalnerechenskaya group objects are located (the largest Filinskoye deposit); in the center, deposits of the Lesozavodskaya group (Turgenevskoye, Tamginskoye); in the south, the Liumao graphite ore giant. Comparative analysis established similarities in their geology, mineralogy, and geochemistry. The results of the isotope-carbon study of Russian and Chinese graphites testify to the derivatives of deep recomposed fluids and isotopically light biogenic substance of the host rocks participating in the ore genesis. The revealed similarity of the mineralogical and geochemical picture of the object formation within the studied zone, due to the common sources of the ore matter, permits to unite them into a single Jiamusi-Khanka province.
\end{abstract}

Keywords: high-carbon rocks, the South of Russia's Far East, Northeast China, graphite, gold, platinum, rare-earth elements, mineralogy, geochemistry, isotopy, deep sources of the ore matter.

\section{REFERENCES}

Galimov, E. M., 1968, Geochemistry of Carbon Stable Isotopes, Moscow, Nedra [In Russian].

Hoefs, J., 2015, Stable Isotope Geochemistry, Berlin, Springer.

Khanchuk, A. I.; Medkov, M. A.; Molchanov, V. P.; Blokhin, M. G., 2014, Development of Approaches to Creating Analytical Methods and Technology for Extracting Useful Components from Graphite-Bearing Rocks, Khimicheskaya Tekhnologiya, 6, 378-384 [In Russian].

Khanchuk, A. I.; Molchanov, V. P.; Androsov, D. V., 2018, First Data about the Manifestations of the NobleMetallically-Rare-Earth Mineralization in the Graphytonic Rocks of the Northern Market of the Khankai Terrain, Doklady Earth Sciences, 482, 2, 1362-1364.

Khanchuk, A. I.; Plyusnina, L. P.; Molchanov, V. P., 2004, First Data on Gold-Platinoid Mineralization in Car- bonaceous Rocks of the Khanka Massif, Primorye, Doklady Akademiyi Nauk, 379, 4, 524-529 [In Russian].

Khanchuk, A. I.; Sun, Fengyue; Molchanov, V. P.; Grebennikov, A. A.; Grebennikov, A. V., 2017, Precious Metals in Graphite-Bearing Rocks of the Liumao Deposit, China, Doklady Earth Sciences, 473, 1, 80-82 [In Russian].

Luque, F.; Crespo, Feo, E.; Barrenechea, J.; Orte$g a, L ., 2012$, Carbon Isotopes of Graphite: Implications on Fluid History, Geoscience Frontiers, 3, 197-207.

Solonenko, V. P., 1951, Geology of Graphite Deposits of East Siberia and the Far East, Moscow, Izd-vo Geol. Liter. [In Russian].

Velivetskaya, T. V.; Ignatyev, A. V.; Reese, M. V.; Kiyashko, S. I., 2006, Express Method of Preparing Liquid and Solid Organic Substance Samples for Isotopic Analysis of Carbon, Mass-Spektrometria, 3, 3, 169-174 [In Russian]. 